\title{
The Book of Jeremiah as Case Study in Asian Contextual Theology
}

\author{
Jerry HWANG \\ Singapore Bible College, Singapore
}

\begin{abstract}
The past decades have seen many calls for Asian contextual theology that is both recognizably Asian and true to the Bible's message. Given the lack of consensus on how to do such theology, however, the present study proposes that the Old Testament itself provides a worthy example to follow. Using the book of Jeremiah as a case study, it is suggested that the prophet's engagement with the historical situation and theological issues of the sixth century BCEfatalism, the identity of the divine vis-à-vis monism, prosperity theology, and cosmic suffering-offers a hermeneutical model for engaging modern Asian religious issues such as Islam, Hinduism, folk religion, and Buddhism.
\end{abstract}

\section{Keywords}

Asian theology, contextualization, Old Testament, Jeremiah, Islam, Hinduism, folk religion, Buddhism

\section{INTRODUCTION}

Dr. Bong Rin Ro, former executive secretary of the Asia Theological Association, influentially declared over thirty years ago,

[I]n Asia the historical and cultural background is quite different from that of the West and demands careful attention from Asian Christians to their own cultures in order to make the gospel relevant to their life situation. Some of the issues we are facing today are Communism, poverty, overpopulation, hunger, suffering, war, demon-possession, bribery, cheating, idolatry, ancestor worship, caste system, secularism, and the resurging Asian religions of Buddhism, Islam and Hinduism. Asian theologians must grapple with these issues and produce Asian theology 
that wrestles with these problems, yet being faithful to the historic teachings of the Scriptures over the centuries. ${ }^{1}$

The societal woes listed by Ro trouble Asia no less today, but the decades since his clarion call have yielded little consensus on how to address them in a manner that is both recognizably Asian and true to the Bible's message. ${ }^{2}$ The reasons for such methodological disagreements in Asian contextual theology are as manifold as the diversity of Asian Christian experiences. ${ }^{3}$ In charting a way forward, however, one underexplored factor has been that proposals for Asian contextual theology overlook how "the whole Bible is itself a 'missional' phenomenon. The writings that now comprise our Bible are themselves the product of and witness to the ultimate mission of God." ${ }^{4}$ Once this false dichotomy between the Bible and cultural engagement is overcome, it becomes evident that Asian contextual theology finds its best source material from the Old Testament and its missional thrust which has arisen from, in, and for Asia. Geographically, Judaism and Christianity arose not in the West but in ancient Israel, which was located on the southwestern end of the Asian continent. ${ }^{5}$ Culturally, the ancient Near East had more in common with the modern Far East than both these regions have had with the modern West. ${ }^{6}$ Thus, retracing the Old Testament's footsteps as ancient Asian contextual theology serves as a form of hermeneutical training to do modern Asian contextual theology.

1 Bong Rin Ro, “Theological Trends in Asia,” Themelios 13 (1987): 57.

2 Timoteo D. Gener and Stephen T. Pardue, "Introduction," in Asian Christian Theology: Evangelical Perspectives, ed. Timoteo D. Gener and Stephen T. Pardue (Carlisle: Langham Global Library, 2019), 2.

3 For a recent survey of Asian contextual theology and a convincing case that it can often be out of touch with lived realities in Asia, see Simon Chan, Grassroots Asian Theology: Thinking the Faith from the Ground Up (Downers Grove: InterVarsity, 2014), 18-41.

4 Christopher J. H. Wright, The Mission of God: Unlocking the Bible's Grand Narrative (Downers Grove: InterVarsity, 2006), 22, italics original.

5 The longstanding truncation of "Asia" into only East Asia is noted by Martin W. Lewis and Kären Wigen, The Myth of Continents: A Critique of Metageography (Berkeley: University of California Press, 1997), 38-40.

6 Cf. D. Premnan Niles, "Example of Contextualization in the Old Testament," The South East Asia Journal of Theology 21 (1980): 19-33. 
Among the Old Testament books one could choose, the book of Jeremiah is particularly promising for Asian contextual theology since it addresses four issues that are urgent in modern Asia: (1) revival and repentance in a world of fatalism, thereby engaging with Islam; (2) the identity of the divine in a world of monism, thereby engaging with Hinduism; (3) prosperity theology in a world of pragmatism, thereby engaging with folk religion; and (4) cosmic justice in a world of suffering, thereby engaging with Buddhism. Reading Jeremiah with Asian eyes not only yields dividends for Asian contextual theology, but it can also offer deeper understanding of a biblical book whose paradoxical character has often frustrated Western readers as "unreadable."7 An Asian, yin-yang approach to Jeremiah keeps the tensive aspects of the book in better balance than a Western approach that employs linear logic and the law of non-contradiction. Indeed, the international calling of Jeremiah as "a prophet to the nations" (1:5) continues to be realized in addressing a modern Asian horizon that stands at a historical and cultural distance from his ancient Asian one.

\section{ReVival and Repentance in a World OF FATALISM: JEREMIAH AND ISLAM}

Israel's greatest moments of revival and repentance lie in the background of Jeremiah. The superscription to the book (Jer 1:1-3) indicates that the prophet ministered from King Josiah's thirteenth year (627 BCE) until the fall of Jerusalem in King Zedekiah's eleventh year (587 BCE). The four decades of Jeremiah's ministry began just before King Josiah initiated his religious reforms in $622 \mathrm{BCE}$ which temporarily overturned centuries of apostasy (2 Kgs 22-23). Josiah's piety led 1-2 Kings to acclaim Josiah as the greatest of Israel's kings: "Before him there was no king like him, who turned to the LORD with all his heart, with all his soul, and with all his might, according to all the law of Moses; nor did any like him arise after him" (2 Kgs 23:25; cf. v. 3). ${ }^{8}$ This allusion to the Shema (Dt 6:4-5) shows that Josiah was both a model Israelite and a model king.

7 Carolyn J. Sharp, Prophecy and Ideology in Jeremiah: Struggles for Authority in DeuteroJeremianic Prose (London: T\&T Clark, 2003): 175.

8 All English Scripture citations are from the NRSV. 
Apostasy in Judah quickly returned when Josiah's son, Jehoiakim, reversed his father's reforms and resumed the apostasy that had already led the northern kingdom of Israel into exile. Correspondingly, repentance faded as a possibility when a significant number of the people couched their refusal to repent as an inability to repent. It was not so much that Judah denied the fact of sinfulness (cf. Jer 2:31; 16:10-11), but rather that they accused Yahweh of failing to make a genuine offer of restoration in the first place: "Why do we sit still? Gather together, let us go into the fortified cities and perish there; for the LORD our God has doomed us to perish, and has given us poisoned water to drink, because we have sinned against the LORD" (8:14). This lament indicates that Judah blamed the inevitability of exile on the trap created by Yahweh's holiness on the one hand, and his unwillingness to offer forgiveness on the other. After the exile Judah also blamed the ancestors for their sins: "The parents have eaten sour grapes, and the children's teeth are set on edge" (31:29; cf. Ez 18:2). With selfcentered statements such as these, Judah claimed that the combination of a distant deity and wicked ancestors meant that destruction had always been unavoidable.

The fatalism of Judah just described has certain resonances with Islam, the world religion that finds its largest number of adherents in modern Asia. ${ }^{9}$ It is important not to generalize fatalism among Muslims as a universal or uniform phenomenon, ${ }^{10}$ but predestination (Arab. al-Qadr) is certainly among Islam's six core beliefs. ${ }^{11}$ The absoluteness of divine omnipotence and omniscience in Islam means that "God is the creator of all the acts of his servants, even as he is the creator of their essences, all that they do, be it good or evil, is in accordance with God's decree, predestination, desire and will." ${ }^{\prime 2}$ While the concepts of human freedom

9 Charles E. Farhadian, Introducing World Religions: A Christian Engagement (Grand Rapids: Baker Academic, 2015), 416-417.

10 Gabriel A. Acevedo illustrates how Islam's relationship to fatalism must include examination of local factors such as income and education level. Overall, however, his cross-cultural analysis demonstrates that Islamic societies have a higher degree of fatalistic orientation than others ("Islamic Fatalism and the Clash of Civilizations: An Appraisal of a Contentious and Dubious Theory,” Social Forces 86, no. 4 [June 2008]: 1737-1740).

11 Shaik Kadir, Islam Explained (London: Marshall Cavendish, 2007), 164.

12 Helmer Ringgren, "Islamic Fatalism," in Fatalistic Beliefs in Religion, Folklore, and Literature: Papers Read at the Symposium on Fatalistic Beliefs Held at Åbo on the 7th-9th of 
and repentance for sin do exist in official Islam (see, for example, Sur. 10:44; 13:11, 31), the practical implications of Allah's radical transcendence and sovereignty leave an existential void that popular Islam fills with other means of making contact with or seeking help from spiritual powers. ${ }^{13}$ Abraham Joshua Heschel observes:

For all the belief in divine mercy, Allah is essentially thought of as unqualified Omnipotence, Whose will is absolute, not conditioned by anything man may do. He acts without regard for the specific situation of man. Since everything is determined by Him, it is a monologue that obtains between Allah and man, rather than a dialogue or a mutuality as in the biblical view. Not the relation between Allah and man, but simply Allah himself is central to Islam. ${ }^{14}$

Precisely for this reason, the debate on how to reconcile al-Qadr with human agency has continued among Islamic thinkers till the present day. ${ }^{15}$

The book of Jeremiah addresses the theological predicament of fatalism by presenting Yahweh's transcendence as the basis and motivation for repentance rather than being opposed to it. In the sign-act narrative of Jeremiah 18, Yahweh has authority to revoke his own decree of destruction if an unrighteous nation repents of its evil, while a righteous nation can still face destruction if it proceeds to do evil (18:7-11). That is, Yahweh wills his prior declarations of a nation's fate to be contingent upon its responsiveness, yet his sovereignty encompasses both the original decree to destroy as well as his subsequent decision to relent. ${ }^{16}$ By combining the traits of authority and flexibility without compromising sovereignty, the God of Jeremiah makes a genuine invitation to repentance that

September, 1964 (Stockholm: Almqvist \& Wiksell, 1967), 59.

13 Bill A. Musk, "Popular Islam: The Hunger of the Heart," in The Gospel and Islam: A 1978 Compendium, ed. Don M. McCurry (Monrovia, CA: Missions Advanced Research and Communication Center, 1979), 218; Max Weber, The Sociology of Religion, trans. Johannes Winckelmann, 4th ed. (Boston: Beacon Press, 1963), 575.

14 Abraham J. Heschel, The Prophets, 2 vols. (New York: Harper \& Row, 1962), 2:21.

15 Zakaria Wanfawan, "Qadar in Classical and Modern Islamic Discourses," International Journal of Islamic Thought 7 (2016): 39-48; Ahmet T. Karamustafa, "Fate," in Encyclopaedia of the Qur'ān, 5 vols., ed. Jane Dammen McAuliffe (Leiden: Brill, 2001), 2:185-188.

16 Terence E. Fretheim, “The Repentance of God: A Study of Jeremiah 18:7-10," Hebrew Annual Review 11 (1987): 81-92. 
contrasts with the near-determinism found in at least one statement of the $Q u$ 'ran: "There is no calamity that befalls the earth or your own selves but in accordance with the law [of causation] before We make it evident" (Sur. 57:22). ${ }^{17}$ As thus understood in the kind of Sunni Islam common in southeast Asia (where the world's most populous Islamic nation, Indonesia, is located), the result of al-Qadr is that "although it is human beings who act, agency is created by God, because God creates all things." ${ }^{18}$

The book of Jeremiah similarly addresses popular religion in Judah, one aspect of which viewed divine sovereignty about judgment as an indication that human repentance was futile. ${ }^{19}$ The apostate people of Yahweh complained, "It is no use! We will follow our own plans, and each of us will act according to the stubbornness of our evil will" (18:12). Yahweh responded that because the people feel that repentance is impossible, their misunderstanding will soon become a reality when destruction by Babylon's hand arrives (18:13-17). Yet this irony occurred not because destruction was part of an impersonal God's unchangeable decree, but because the people made a self-fulfilling prophecy that rationalized their disobedience toward Yahweh. Jeremiah 18 thus challenges fatalism by showing that apostasy comes from human unwillingness to repent rather than a divine unwillingness to accept it.

\section{The IdentiTy OF THE Divine IN A WORLD OF MONISM: JEREMIAH AND HinduISM}

A major obstacle for Asian contextual theology has been the common assertion in Western thinking that the Bible itself stands opposed to Eastern approaches to reality as monistic, whether ancient or modern. As expressed by Old Testament scholar John Oswalt, for example, the Eastern concept of continuity holds that

17 This rendering comes from Ahmed Ali, Al-Qur'ān: A Contemporary Translation (Princeton: Princeton University Press, 2001), 471.

18 Fauzan Saleh, Modern Trends in Islamic Theological Discourse in $20^{\text {th }}$-Century Indonesia: A Critical Study (Leiden: Brill, 2001), 118.

19 On the diversity of Judah's popular religion in the time of Jeremiah, see Susan Ackerman, Under Every Green Tree: Popular Religion in Sixth-Century Judah (Leiden: Brill, 2001), 5-35. 
the visible world is only a reflection of the invisible, divine world, but as its reflection it is identical with it. A popular term for this is pantheism: the divine is everything and everything is the divine. Hinduism is perhaps the most developed expression of this thought. ${ }^{20}$

He goes on to propose that the Bible endorses a form of Western dualism, ${ }^{21}$ even though this worldview has been a key feature of the Enlightenment's anti-Christian and anti-supernatural posture toward reality. ${ }^{22}$

Oswalt's description of East and West contains true aspects yet also borders on caricature, thus raising the question of how to draw meaningful comparisons between the Bible and Hinduism for the sake of doing contextual theology. The latter is a sprawling belief system that has absorbed opposing elements through the centuries, such as atheism, theism, pantheism, and polytheism. Besides the countless regional variations on the Indian subcontinent for what Hinduism is (itself an oversimplification), the "official" Hinduism of India's cities differs noticeably in its manifestations from "village" Hinduism. Yet, despite these difficulties, it is notable that astrology transcends these categories as a multifaceted part of Hindu selfunderstanding through the centuries. Not only does the Indian on the street tend to summarize their working theology with the dictum "Astrology is karma," 23 but the formal astrological discipline of jyotisha (Sansk. "light in the sky, luminary”) also plays a significant role in several Hindu scriptures, calendrical systems, horoscopes, and rituals. ${ }^{24}$ And most relevantly for this study, Hindu astrology developed significantly with the Hellenistic introduction of the same kinds of Mesopotamian astrology that the book of Jeremiah identifies as a temptation for Judah. ${ }^{25}$ It is likely that the celestial

20 John N. Oswalt, The Bible among the Myths: Unique Revelation or Just Ancient Literature? (Grand Rapids: Zondervan, 2009), 49, italics added.

21 Oswalt, The Bible among the Myths, 63-84.

22 As famously demonstrated by Paul G. Hiebert, "The Flaw of the Excluded Middle," Missiology 10 (1982): 35-47.

23 François Chenet, "Karma and Astrology: An Unrecognized Aspect of Indian Anthropology," Diogenes 33 (1985): 102, italics original. For more on astrology's role in "everyday Hinduism," see Joyce Burkhalter Flueckiger, Everyday Hinduism (Chichester: Wiley-Blackwell, 2015), 211-218.

24 Michio Yano, "Calendar, Astrology, and Astronomy," in The Blackwell Companion to Hinduism, ed. Gavin Flood (Malden: Blackwell, 2005), 376-392.

25 On the parallels between Mesopotamian and Indian rituals, see Toke Lindegaard 
divination rituals in the Mesopotamian texts of Enuma Anu Enlil stand in the backgrounds of both Hindu jyotisha and Judah's syncretism with astral religion in the time of Jeremiah. ${ }^{26}$

The book of Jeremiah enjoins the fearful people of Yahweh: "Do not learn the way of the nations, or be dismayed at the signs of the heavens; for the nations are dismayed at them" (10:2). While this statement clearly prohibits Mesopotamian omen interpretations of the kind set forth in Enuma Anu Enlil, it is notable that the rest of Jeremiah does not offer the equivalent of a Western, demythologized approach to an impersonal "nature" in place of Eastern pantheism. Instead, Jeremiah offers a rich account of a God-ordained, personal, and active creation that exemplifies the ability of the Old Testament to navigate "a middle course between the Gnostic contempt for nature and the pagan adoration of it." ${ }^{37}$

Creation is a key character with its own roles and voices in the book of Jeremiah. In chapters 2-4, for example, the covenant that Yahweh first made with his people is described as a fertile plant that grew in the wilderness and enjoyed protection from its enemies (2:2-3). As Judah strayed by pursuing fertility practices (2:27-28), however, its apostasy encountered the reality that such rituals backfired with infertility (2:20-21). These uses of creational images are not merely metaphors, for creation itself participates in the theological drama when Yahweh enjoins the heavens, "Be appalled, O heavens, at this, be shocked, be utterly desolate, declares the LorD" (2:12). The heavens are hereby summoned as investigators to confirm that Judah's deconversion from Yahweh has no precedents in history (cf. 2:9-11). The verification of Judah's sin then means that creation will shift its role to

Knudsen, "House Omens in Mesopotamia and India," in From the Banks of the Euphrates: Studies in Honor of Alice Louise Slotsky, ed. Micah Ross (Winona Lake: Eisenbrauns, 2008), 121-133. The commercial and cultural factors that drove the connections between the Near East and India are discussed by Stephan Hillyer Levitt, "The Dating of the Indian Tradition," Anthropos 98 (2003): 341-359.

David Burnett, The Spirit of Hinduism: A Christian Perspective on Hindu Thought (Tunbridge Wells: Monarch, 1992), 115; David E. Pingree, "Mesopotamian Astronomy and Astral Omens in other Civilizations," in Mesopotamien und seine Nachbarn: politische und kulturelle Wechselbeziehungen im alten Vorderasien vom 4. bis 1. Jahrtausend v. Chr., ed. Hans Jörg Nissen and Johannes Renger, Rencontre Assyriologique Internationale 25, 2 vols. (Berlin: D. Reimer, 1982), 2:613-631.

27 Northrop Frye, The Great Code: The Bible and Literature (London: Routledge \& Kegan Paul, 1982), 112-113, quoted in Terence E. Fretheim, God and World in the Old Testament: A Relational Theology of Creation (Nashville: Abingdon Press, 2005), xi. 
enforcer of Yahweh's verdict, as when drought takes hold (2:13) and lions invade Judah's land (2:15). Yet, as Judah continues to defile its land through Canaanite nature religion (3:1-5), Yahweh offers another opportunity for his people to repent using a series of creational images: "Break up your fallow ground and do not sow among thorns. Circumcise yourselves to the LORD, remove the foreskin of your hearts, O people of Judah and inhabitants of Jerusalem, or else my wrath will go forth like fire, and burn with none to quench it, because of the evil of your doings" (4:3-4).

The final failure of Judah to respond means that creation must become both the victim and agent of Judah's sins that lead to exile (4:23-26). Notable in this section is the statement that "the earth shall mourn, and the heavens above grow black" (4:28), thereby identifying a disintegrating creation as a partner closely related to Judah's destruction. The domain of history remains present but has been subsumed within creation as a theological topos. And against an enduring Western tendency to reduce creational descriptions of history to just a figure of speech or literary device, Terence Fretheim notes that

the use of creation language is not used simply to draw analogies between these activities of God. Creation language is used more basically to give cosmic depth to God's historical activity.... Israel's comprehensive belief in God as Creator serves Israel's confession in God as Redeemer and the latter reinforces Israel's confession of God as Creator. ${ }^{28}$

In this regard, Jeremiah's account of a personified creation that is everywhere alive yet also relational presents a stark contrast to the account of the Brahman in the Upanishads as an all-pervading reality which is everywhere alive but tends toward an impersonal cosmic principle. ${ }^{29}$ Interestingly, however, Asian theologians have been prone to a caricature of Jeremiah's unique response to celestial divination in its cultural context. In the entry on "Astrology" in the South Asia Bible Commentary, Jeremiah 10:2 is rightly cited as biblical evidence that "we are not to follow others [i.e., astrologers] or what the stars foretell." But in this same article by an Indian theologian, the statement that "God has already given us all the

28 Fretheim, God and World in the Old Testament, 10-11.

29 Frank Whaling, Understanding Hinduism (Edinburgh: Dunedin Academic, 2010), 3738; D. S. Sarma, Essence of Hinduism (Bombay: Bharatyia Vidya Bhavan, 1971), 91. Cf. Karan Singh, Essays on Hinduism, 3rd ed. (Delhi: Primus Books, 2014), 5. 
knowledge we need for the future through his inspired word" 30 reflects a more Western penchant for abstraction that clashes with Jeremiah's more Eastern penchant for concreteness. At the same time, Jeremiah does not reflect a monist worldview that ascribes sacral power to the physical world, as the Rigvedic hymns to the sun-god Savitr do. ${ }^{31}$

In fact, Jeremiah not only speaks frequently about both creation and history, but the book that bears his name also assigns the stars in heaven the highest honor of testifying to the efficacy of Yahweh's mighty acts in both realms. The "new covenant" oracle of Jeremiah 31 closes with the declaration that the regularity of the heavenly bodies supplies proof that his people will continue to exist:

Thus says the LORD, who gives the sun for light by day and the fixed order of the moon and the stars for light by night, who stirs up the sea so that its waves roar-the LoRD of hosts is his name: If this fixed order were ever to cease from my presence, says the LoRD, then also the offspring of Israel would cease to be a nation before me forever. Thus says the LoRD: If the heavens above can be measured, and the foundations of the earth below can be explored, then I will reject all the offspring of Israel because of all they have done, declares the LORD. (31:35-37)

The stars in the sky thus have a revelatory function in asserting the character of God, but one that mediates between a Western tendency to demythologize "nature" in favor of timeless propositions on the one hand, and the Eastern tendency on the other to mingle physical things with spiritual beings that can determine the courses of humanity. In this and other ways, the book of Jeremiah illustrates how to move beyond the eitheror choices of history vs. myth, history vs. creation, and transcendence vs. immanence in a distinctive manner that builds bridges between Western dualism and Eastern monism. ${ }^{32}$

30 M. T. Cherian, "Astrology," in South Asia Bible Commentary: A One-Volume Commentary on the Whole Bible, ed. Brian C. Wintle (Grand Rapids: Zondervan Academic, 2015), 533 , italics added.

31 Margaret Stutley, Hinduism: The Eternal Law: An Introduction to the Literature, Cosmology and Cults of the Hindu Religion (Wellingborough: Aquarian Press, 1985), 20.

32 The dominant view that the Bible pits a linear and demythologized perspective on history against the cyclical and mythic orientation of creation is granted even by an Asian theologian like Kosuke Koyama (Waterbuffalo Theology, 25th anniversary ed. [Maryknoll: Orbis, 1999], 20-31) and a missiologist like Paul G. Hiebert, Transforming 


\section{Prosperity Theology in a World of Pragmatism-Jeremiah and FolK RELIGION}

The previous two sections about Jeremiah's relevance to Islam and Hinduism primarily concerned the realm of "high" religion. But as hinted already, "low" religion tends to occupy the void when felt needs go unmet by the complexity of institutions or rituals that worshipers perceive in its more formal counterpart. The primal urgency of immanence over transcendence typically gives rise to trying an eclectic mixture of inputs for the "piety-prosperity equation" so that worshipers may receive blessing and avoid curse. When contact between different cultures is frequent, as when tiny Israel subsisted among larger empires or when Christianity arrived in East Asia with its already-established religions, the stage is set for a syncretism that mixes old and new.

Jeremiah 44 addresses precisely this scenario of the Jewish refugees after they leave their homeland. In this narrative set in Egypt, the Jewish community reveals its pragmatism concerning which deity it will choose as they begin their diaspora existence. The people have evidently not learned the lesson that Jerusalem fell due to their apostasy (vv. 2-9). Thus they fail to heed Jeremiah's warning that history will soon repeat itself in Egypt (vv. 10-14), insisting instead that their veneration of other gods yielded better results than repentance toward Yahweh ever did (vv. 15-17). They are particularly contemptuous toward Josiah's reforms, which did away with other deities such as the "queen of heaven": "But from the time we stopped making offerings to the queen of heaven and pouring out libations to her, we have lacked everything and have perished by the word and by famine" (v. 18).

Because the queen of heaven was a Babylonian fertility deity thought to rule the heavenly hosts, it is no accident that Jeremiah 44 refers four times to the God of Israel as "the LORD of hosts" or "the LoRD God of hosts" (vv. 2, 7, $11,25)$ rather than as "your God," as the preceding chapters tend to do (for example, in $40: 2 ; 42: 2-5,13,20,21)$. The need to emphasize the sovereignty of Yahweh over all realms is due to Judah's superstition that "the right

Worldviews: An Anthropological Understanding of How People Change (Grand Rapids: Baker Academic, 2008), 338. For an extended critique of this idea, see the response essays in Jörn Rüsen, ed., Western Historical Thinking: An Intercultural Debate (New York: Berghahn Books, 2002). 
deed at the right moment, or the wrong deed at the right moment, will inexorably be followed by results good or bad." ${ }^{33}$ As Judah misinterpreted its recent history in the exile, the correlation between venerating the queen of heaven and experiencing prosperity has hereby been conflated with the causation that suffering must be the effect of rejecting her in favor of Yahweh.

Such a mechanistic worldview is common in Asia for reducing the supernatural (whether conceived as impersonal forces or personal deities) into a means toward practical ends such as prosperity, health, and fertility. Because people continue to pay homage to their own god or gods in syncretism, two conclusions quickly follow. The first is that the experience of blessings becomes proof of one's piety, while the opposite experience of curses can be nothing other than impiety. This may sound like the OT's retribution principle that sin generally leads to suffering, but the principle has actually been reversed and hardened into an absolute law-all suffering comes from sin, while all prosperity comes from righteousness. ${ }^{34}$ This is not the OT's own understanding of causality but the Eastern religious law of karma with which Job's friends concluded that his suffering proved that he had sinned.

More will be said below on karma and suffering in the discussion of Jeremiah and Buddhism, but it is pertinent to note that a pragmatic approach to deity is common in societies influenced by Chinese folk religion with its mixture of Confucianism, Taoism, Buddhism, ancestor worship, and animistic elements. ${ }^{35}$ Even in a more westernized society such as Singapore, for example, the nation's core values of meritocracy and self-determination reflect a synthesis of ancient Chinese humanism and the modernizing presence of Western and/or Christian institutions. ${ }^{36}$ As a

33 Edwin M. Good, Irony in the Old Testament, 2nd ed. (Sheffield: Almond Press, 1981), 197-198.

34 On the impossibility of flattening the OT's various depictions of retribution, see Stephen B. Chapman, "Reading the Bible as Witness: Divine Retribution in the Old Testament," Perspectives in Religious Studies 31 (2004): 171-190.

35 Farhadian, Introducing World Religions, 256; Winfried Corduan, Neighboring Faiths: A Christian Introduction to World Religions, 2nd ed. (Downers Grove: IVP Academic, 2012), 410.

36 Clive S. Chin, The Perception of Christianity as a Rational Religion in Singapore: A Missiological Analysis of Christian Conversion (Eugene: Pickwick Publications, 2017), 82-88. 
result, this city-state has witnessed the religious pragmatism of seeking a variety of powers or deities joining forces with the secular pragmatism of Western capitalist principles and education in Christian-heritage mission schools to ensure prosperity for the nation. ${ }^{37}$

Against a similar line of pragmatic thinking, however, the God of Jeremiah reminds his people that he is not a magical force to be manipulated, nor one of many deities with whom they can hedge their bets. The burning question of the Jewish community, "Was it ever worth it to follow Yahweh?," is certainly natural and not irrelevant. Jeremiah 44 nonetheless refutes such logic in a comprehensive manner both by asserting the uniqueness of Yahweh as "God of Israel" and by having him take over the queen of heaven's perceived powers and benefits as "God of hosts" (v. 7) — military, celestial, or otherwise.$^{38}$ In sum, the narrative depicts Yahweh as patient enough to allow folk religion to deconstruct itself via the futility of seeking whichever source of power is convenient at the moment (v. 28).

\section{COSMIC JUSTICE IN A WORLD OF SUFFERING: JEREMIAH AND BUDDHISM}

Along with Ecclesiastes, the book of Jeremiah is particularly suited to the existential questions of Buddhism. The intensity of Jeremiah's multifaceted exploration of evil, suffering, and theodicy is mirrored by these being some of Buddhism's main themes. As Farhadian observes, "The seriousness with which Buddhism recognises and addresses suffering makes it an eminently appealing tradition for many. Everyone suffers. What is striking about Buddhism is the acute attention the tradition pays to analyzing and providing a cure for the universality of suffering." 39

A comparison of suffering in Buddhism and Jeremiah will illustrate certain similarities between them. Like Siddhartha's Four Sights of dukkha

37 Brett McCracken, "How the Gospel Takes Root in "Crazy Rich" Singapore," September 24, 2018, https://www.thegospelcoalition.org/article/gospel-takesroot-crazy-rich-singapore/, accessed November 11, 2019).

38 In fact, the overlap between Yahweh and the "queen of heaven" is significant to the extent that some scholars wonder if Jeremiah 44's polemic against idolatry deconstructs itself because these two deities are too similar (for example, Teresa Ann Ellis, "Jeremiah 44: What If 'the Queen of Heaven' is YHWH?," Journal for the Study of the Old Testament 33 [2009], 465-488).

Farhadian, Introducing World Religions, 138. 
(that is, suffering), which led him to seek answers about the cause of and solution for suffering in the Four Noble Truths, the ministry of Jeremiah began with two visions that concern his work as the one who undeniably suffers the most among the OT prophets (1:11-18). As Siddhartha grew into the Lord Buddha, the pathway to enlightenment that he advocated in the Eightfold Path (in Chinese, the ba zheng dao) has notable similarities to Jeremiah's insistence that he is no theological innovator. Similarly to other Eastern religions, Jeremiah instead enjoins Judah to proceed along a well-known dao ("way, path"): "Stand at the crossroads and look, and ask for the ancient paths [gu dao], where the good way [shan dao] lies; and walk $[x i n g]$ in it; and find rest for your souls" (6:16). ${ }^{40}$ But as the prophet's failures and setbacks drive him to utter despair, he cries out, "Why did I come forth from the womb to see toil and sorrow [lao lï chou ku], and spend my days in shame?" (20:18). ${ }^{41}$ All this is not to argue that Buddhism and Jeremiah supply the same answers to life's questions, simply to note that the act of translating Jeremiah into an Asian language such as Chinese inevitably brings the book into the same lexical field of suffering, evil, and retribution as Buddhist terminology. One major difference in Jeremiah's use of these terms, for example, is to express frustration that the expected link between sin and punishment is missing (as in the prophet's "Confessions" of chapters 11-20).

On this note, the prominence of retribution themes in Jeremiah suggests a conceptual bridge with the varied belief systems that come under the label "Buddhism." The concept of karma provides an entrée into all schools of Buddhism, as Damien Keown observes, since "[b]elief in karma is a constant which underlies the philosophical diversity of the many Buddhist schools, and it is one of the few basic tenets to have escaped major reinterpretation over the course of time." ${ }^{42}$ The nature of karmic justice varies in different Buddhist systems, but it always contains the feature that reward (good karma) and retribution (bad karma) for one's life's actions are passed on to the next through samsara (reincarnation). ${ }^{43}$ The fact that

40 On the commonality of Dao/Tao across Chinese religions, see Enoch Wan, "TaoThe Chinese Theology of God-Man," His Dominion 11 (1985): 24-27.

41 The quotations in brackets are from the Chinese Union Version of the Bible.

42 Damien Keown, "Karma, Character, and Consequentialism," Journal of Religious Ethics 24 (1996): 329-350, here 329.

Bruce R. Reichenbach, "The Law of Karma and the Principle of Causation," 
suffering is both the outgrowth of past karma and an opportunity to improve future karma leads Buddhists (and often Asians in general) to a paradoxical question - is suffering in one's present life a shameful burden to be rejected or a meritorious gift to be embraced?

This paradox receives a nuanced answer in Jeremiah's interaction with the misunderstandings of divine retribution in his time. Particularly in chapters 28-29, the book of Jeremiah affirms that suffering happens because punishment is necessary, but redemption and restoration are possible in this life rather than the next. On the one hand, Jeremiah 28 addresses the presumption of the false prophet Hananiah that the exile is unnecessary and will soon be reversed. Hananiah sets forth a "positive" version of karmic theology that conflates divine power to save with divine willingness to do so (28:2-4), resulting in the false expectation that Yahweh must end the deportation of the Judeans and Jehoiachin their king on Hananiah's terms (namely, within two years). On the other hand, Jeremiah 29 contains a letter of reassurance to the exiles who have fallen into "negative" karmic theology-the notion that restoration is impossible because Yahweh is either unwilling or unable to deliver his people from Babylon (29:8-9). Jeremiah responds that exile was not only a punishment, but also an act of preservation for the refugees in Babylon (29:10-14).

Thus in his response to both forms of karmic theology, Jeremiah's multifaceted message could be framed in Buddhist terms as such-dukkha is real because the law of karma must apply for sins committed, but karma results from the intervention of a personal God rather than from the causality of an impersonal universe. Because of this relational involvement, the punishment of karma is intended to bear good fruit in one's present existence rather than only in a future one, making samsara across lives unnecessary for redemption to take place. The exile will be neither short nor forever, yet it aims toward the greater purpose of restoration from exile.

Or in Chinese Buddhist terms, the proverb about retribution that "vice begets curse, virtue begets blessing" (e you e bao, shan you shan bao) is challenged when Jeremiah asserts that the putatively simple one-toone relationship between cause and effect is actually a many-to-many relationship. Though the vice of apostasy begets the curse of exile, exile is

Philosophy East and West 38 (1988): 399-410. 
not an end in itself but another opportunity for virtue, as when the Jewish refugees in Babylon are implored to use their humiliation as an opportunity to learn virtue rather than vice. Moreover, the curse of exile is a blessing in disguise since life in Babylon offers a sanctuary for the refugees (29:4-7) who would otherwise not survive the final destruction of Jerusalem. The retributive aspect of suffering therefore continues to function but contains a this-worldly restorative aspect. Not only this, but the prophet who was predestined for suffering (1:17-19) becomes a theological symbol because of his Creator God's suffering, weeping, and messy involvement with his own creatures in the drama of redemption (9:1-3).

Jeremiah's depiction of multiple purposes for the exile demonstrates how cosmic justice by its nature requires multiple causes and effects. This conclusion undercuts both Western and Eastern approaches to theodicy, though in different ways. In the West, redaction criticism tends to fragment Jeremiah's variety into supposedly irreconcilable literary layers rather than keeping them in dialogical tension. ${ }^{44}$ Judgment and deliverance are then reckoned to different periods of Jeremiah's message. Interestingly in the East, religions such as Buddhism share this tendency to treat reward and retribution as monolithic concepts that are mutually exclusive, except that the separation between supposedly contradictory ideas occurs across human incarnations instead of literary layers. ${ }^{45}$ In both parts of the world, however, such understandings of suffering offer unsatisfying answers for why the righteous often suffer and the unrighteous often prosper. The ensuing reductionism becomes a forced choice between prosperity theology and blaming the victim.

\section{Conclusion}

It is far from coincidental that Kosuke Koyama's ground-breaking book on Asian contextual theology, Waterbuffalo Theology, mentions Jeremiah more than any other in the Old Testament. ${ }^{46}$ Of course, the book of

44 Cf. Robert P. Carroll, "Synchronic Deconstructions of Jeremiah: Diachrony to the Rescue? Reflections on Some Reading Strategies for Understanding Certain Problems in the Book of Jeremiah," in Synchronic or Diachronic? A Debate on Method in Old Testament Exegesis, ed. J. C. de Moor (Leiden: Brill, 1995), 39-51.

45 Cf. A. R. Wadia, "Philosophical Implications of the Doctrine of Karma," Philosophy East and West 15 (1965): 145-152.

Koyama’s Waterbuffalo Theology contains references to Jeremiah on pp. 8, 42, 84, 86, 
Jeremiah does not mention any water buffaloes, but its international scope (Jer 1:5, 10; chaps. 25, 46-51) makes it uniquely suited to address the theological, cultural, and ethical issues in the modern Far East that parallel its original context in the ancient Near East. Other OT books besides Jeremiah are needed in providing comprehensive answers to the Asian questions that Bong Rin Ro and others raise (for example, Genesis on creation myths, Exodus on liberation, Obadiah on empire, Joel on environmental ruin, Esther on diaspora living), so the present study on Jeremiah has sought to be illustrative of theological possibilities rather than being comprehensive. But if Asian Christians could emulate their African counterparts in embracing fully the affinities between the Old Testament and their cultural context, ${ }^{47}$ this would go a long way toward acknowledging this part of the Bible as the indigenous theological message for Asia that it has always been.

\section{About author}

Jerry Hwang (PhD, Wheaton College), is academic dean of the School of Theology (English) and associate professor of Old Testament at Singapore Bible College, Singapore.

109, 137-139, and 155-156.

47 As observed by Knut Holter, a South African OT scholar: "Just as the OT has proved to be an African book, to do OT scholarship has likewise proved to be an African enterprise. Therefore, wherever African OT scholarship will be heading, with regard to institutional context and thematic orientation, it deserves attention" ("The Current State of Old Testament Scholarship in Africa: Where Are We at the Turn of the Century?," in Interpreting the Old Testament in Africa: Papers from the International Symposium on Africa and the Old Testament in Nairobi, October 1999, ed. Knut Holter, Mary N. Getui, and Victor Zinkuratire [Nairobi: Acton Publishers, 2002], 25). Cited in Aloo O. Mojola, "The Old Testament or Hebrew Bible in Africa: Challenges and Prospects for Interpretation and Translation," Verbum et Ecclesia 35 (2014): 7. 